\title{
Cytotoxic agarofurans from the seeds of the Australian rainforest vine Celastrus subspicata
}

Anthony R. Carroll, ${ }^{\mathrm{a}}$ Rohan A. Davis, ${ }^{\mathrm{a}}$ Rama Addepalli, ${ }^{\mathrm{a}}$ Gregory A. Fechner, ${ }^{\mathrm{a}}$ Gordon P. Guymer, ${ }^{\mathrm{b}}$ Paul I. Forster ${ }^{\mathrm{b}}$ and Ronald J. Quinn ${ }^{\mathrm{a} *}$

Eskitis Institute, Griffith University, Brisbane, Queensland 4111, Australia and Queensland Center for Biodiversity, Queensland Museum, South Brisbane, Queensland 4101, Australia

*To whom correspondence should be addressed. Tel: 6173735 6000, Fax: 6173735 6001. Email R.Quinn@griffith.edu.au.

${ }^{\mathrm{a}}$ Griffith University.

${ }^{\mathrm{b}}$ Queensland Herbarium 
Abstract: An anti-inflammatory active extract from the seeds of the Australian rainforest vine Celastrus subspicata was identified from high throughput screening of a plant and marine invertebrate extract library using an assay which detects down regulation of expression of pro-inflammatory genes associated with the glucocorticoid receptor ligand complex. The anti inflammatory properties of the extract were found to be associated with a group of fatty acids that were present in the extract in high yield. Two agarofurans were also isolated and shown to possess minimal anti inflammatory activity and to be cytotoxic towards HeLa cancer cells.

Keyword index: Celastrus subspicata; Celastraceae; glucocorticoid receptor; cytotoxicity; agarofuran sesquiterpene. 


\section{Introduction}

Nicolaou et al (2000) consider dihydro- $\beta$-agarofurans to be "privileged structures" since many show cytotoxic (Kuo et al. 1994), ant-HIV (Duan et al. 1999), immunosuppressive (Zheng et al. 1989) and insecticidal (Wu et al. 2001) activities. Plants from the family Celastraceae have been intensively investigated mainly because many species contain dihydro- $\beta$-agarofurans and these compounds appear to be taxonomic markers for the family (Brüning and Wagner 1978). Our interest in an Australian species Celastrus subspicata Hook (Celastraceae) was sparked by the observation that the $\mathrm{CH}_{2} \mathrm{Cl}_{2}$ extract from the seeds exhibited anti-inflammatory activity associated with the glucocorticoid receptor (GR). C. subspicata is a vine which is found in rainforests and monsoon forests from far north Queensland to southern New South Wales. It is also found in Papua New Guinea and New Caledonia. Nuclear hormone receptors are ligand-inducible transcription factors and one, the GR, is associated with inflammatory and immunosuppressive properties (Pujols et al. 2004; Bamberger et al. 1996). The GR functions as a transcription factor upon binding of glucocorticoids (GCS) and the major antiinflammatory effects of the GR-GSC complex are a result of the down regulation of genes via interaction of the complex with transcription factors such as activator protein-1 (AP-1). The GR-GCS binds to AP-1 via a protein-protein interaction and prevents AP-1 binding to the TPA responsive element (TRE) causing down regulation of pro-inflammatory genes that are usually activated by AP-1 (Kumar and Thompson 2005; Hayashi et al. 2004). Synthetic ligands of the GR are widely used as drugs to treat inflammatory conditions such as rheumatoid arthritis or dermatitis. Unfortunately many of these drugs produce side effects which appear to be associated with up regulation of genes encoding antiinflammatory proteins, such as secretory leukoprotease inhibitor (SLPI), $\beta_{2}$-adrenoceptors, and CD163. The discovery of compounds which selectively down regulate pro-inflammatory genes may provided new and improved drug therapies to treat inflammatory conditions.

\section{Results and discussion}


A reporter gene assay in which multiple TRE elements were linked to a minimal promoter driving the $\beta$ galactosidase gene was employed to find natural product extracts that down regulate pro-inflammatory genes. High throughput screening of extracts from 7399 plants and 517 marine invertebrates collected in Queensland led to the discovery of a bioactive $\mathrm{CH}_{2} \mathrm{Cl}_{2}$ extract from the seeds of $C$. subspicata. Purification of this extract resulted in the isolation of two new agarofuran sesquiterpenes, $\mathbf{1}$ and $\mathbf{2}$. This paper reports on the isolation, structure determination and biological activity of the constituents isolated from C. subspicata.

The $\mathrm{CH}_{2} \mathrm{Cl}_{2}$ extract was partitioned between $90 \%$ aq. $\mathrm{MeOH}$ and hexane. The hexane contained very high concentrations of fatty acids that, by NMR and MS, could be assigned to mainly palmitic, oleic and linoleic acid. The aqueous methanol fraction was purified on $\mathrm{C}_{18}$ yielding compounds $\mathbf{1}$ and $\mathbf{2}$. The antiinflammatory properties of the extract was attributed mainly to the hexane fraction and assays performed on authentic samples of the fatty acids, palmitic, oleic and linoleic acids showed that the three acids were active with linoleic acid being the most potent. The agarofurans, $\mathbf{1}$ and $\mathbf{2}$ showed minimal activity in the reporter gene assay and were also shown to be mildly cytotoxic.

Compound $\mathbf{1}$ was isolated as a colourless optically active gum. Accurate mass analysis of the $[\mathrm{M}+\mathrm{Na}]^{+}$ ion at $m / z 575.2268$ in the (+) HRESIFTMS indicated 1 had a molecular formula $\mathrm{C}_{31} \mathrm{H}_{36} \mathrm{O}_{9}$. IR absorption bands at $3468,1730,1719 \mathrm{~cm}^{-1}$ suggested hydroxyl and ester groups were present in the molecule. The ${ }^{1} \mathrm{H}$ NMR spectrum of $\mathbf{1}$ contained signals for four quaternary methyl groups $\left[\delta_{\mathrm{H}} 1.39(\mathrm{H}-\right.$ 11), $1.58(\mathrm{H}-13), 1.57(\mathrm{H}-14)$ and $1.63(\mathrm{H}-15)]$, an acetate methyl at $\delta_{\mathrm{H}} 1.42$ and two benzoates $\left[\delta_{\mathrm{H}} 7.47-\right.$ 8.21, (10H)]. Analysis of HMQC and DEPT spectra demonstrated that compound $\mathbf{1}$ contained, in addition to the methyl and phenyl groups, four oxygenated methines, an aliphatic methine and two aliphatic methylenes. The remaining seven carbons observed in the ${ }^{13} \mathrm{C}$ NMR spectrum were quaternary (three ester carbonyls, three oxygenated aliphatic and one aliphatic carbon). Partial structures 
$\mathrm{RCH}_{2} \mathrm{CH}_{2} \mathrm{CHROR}$ and RCHORCHORCHR were deduced from COSY correlations. HMBC

correlations observed from the four aliphatic methyl proton signals and the oxygenated methine proton H-6 provided sufficient information to assign the dihydroagarofuran core of the structure. Thus a cyclohexyl partial structure was deduced from correlations from H-14 to the methylene carbon C-3, and the two oxygenated quaternary carbons $\mathrm{C}-4$ and $\mathrm{C}-5$ and from $\mathrm{H}-15$ also to $\mathrm{C}-5$, to the quaternary aliphatic carbon $\mathrm{C}-10$, as well as to the oxygenated methine carbon $\mathrm{C}-1$ that was part of the same $\mathrm{CH}_{2} \mathrm{CH}_{2} \mathrm{CH}$ partial structure as $\mathrm{C}-3$. An additional correlation was observed from $\mathrm{H}-15$ to the oxygenated methine $\mathrm{C}-9$ and from the two methyl proton signals, $\mathrm{H}-12$ and $\mathrm{H}-13$ to the methine carbon C-7. Finally HMBC correlations from H-6 to C-4, C-5, C-7, C-10 and C-11 indicated that 1 possessed a decahydronaphthylene substituted by methyl groups at C4, and C10 and an isopropyl group at C7. The ${ }^{13} \mathrm{C}$ NMR quaternary carbon signals at $\delta_{\mathrm{C}} 92.7(\mathrm{C}-5)$ and $83.0(\mathrm{C}-11)$ were characteristic of ether carbons of an agarofuran (Chang et al. 2003). The acetate was located at C-1 since HMBC correlations were observed between $\mathrm{H}-1$ and the acetate carbonyl carbon at $\delta_{\mathrm{C}} 170.2$. The two benzoates were attached at C-6 and C-9 since correlations were observed from the protons H-6 and H-9 to carbonyl carbons at $\delta_{\mathrm{C}}$ 165.9 and 164.9, respectively. The relative configurations of the eight stereogenic centers in 1 were established on the basis of coupling constants and correlations observed in a NOESY spectrum. Since H-1, H-3a and H-9 showed NOESY correlations to each other it could be concluded that the decahydronaphthylene adopted a chair-chair conformation with these three substituents occupying axial positions. The isopropyl group was also axial since a correlation was observed between H-9 and H-13. On the opposite face of the molecule, $\mathrm{H}-11, \mathrm{H}-6$, and $\mathrm{H}-15$ were all axial since they showed correlations to each other. The molecule had to contain a trans bridgehead for the above correlations to be observed. The coupling constant of $4.2 \mathrm{~Hz}$ between H-7 and H-8 indicated that these protons were both equatorial. Compound 1 was therefore concluded to be $1 \alpha$-acetoxy- $4 \beta, 8 \alpha$-dihydroxy- $6 \beta, 9 \alpha$-dibenzoyl- $\beta$ agarofuran. 
A $[\mathrm{M}+\mathrm{Na}]^{+}$ion peak at $m / z$ 617.2348 in the (+) HRESIFTMS of compound 2 allowed a molecular

formula $\mathrm{C}_{33} \mathrm{H}_{38} \mathrm{O}_{10}$ to be assigned. The ${ }^{1} \mathrm{H}$ and ${ }^{13} \mathrm{C}$ NMR spectra of 2 were almost identical with those of 1. The only significant difference was the addition of signals that could be assigned to an acetate $\left[\delta_{\mathrm{H}}\right.$ 2.18; $\delta_{\mathrm{C}} 20.7$ and 169.9] and the $1.12 \mathrm{ppm}$ downfield shift of $\mathrm{H}-8$ from $\delta_{\mathrm{H}} 4.47$ to 5.59 . These data indicated that $\mathbf{2}$ was the 8 -acetyl derivative of $\mathbf{1}$ and this was confirmed from analysis of COSY, HMQC, HMBC and NOSEY spectra.

Agarofurans $\mathbf{1}$ and $\mathbf{2}$ are most closely related to two compounds isolated from Celastrus paniculatus since these are the only other agarofurans which possess the same oxygenation pattern and configuration at the 8 stereogenic centers (Tu et al. 1993).

Compounds 1 and $\mathbf{2}$ showed minimal activity (12\% and 38\% inhibitory activity respectively) in the proinflammatory gene down regulation assay at a concentration of $100 \mu \mathrm{M}$. However, both compounds were also shown to be cytotoxic to HeLa cells at a concentration of $100 \mu \mathrm{M}(\mathbf{1}, 73 \%$ and $\mathbf{2}, 85 \%$ inhibition). The fatty acids, linoleic acid, oleic acid and palmitic acid were tested in the proinflammatory gene down regulation assay. All three acids decreased $\beta$-galactosidase activity although both oleic and palmitic acid failed to reach basal activity at $1 \mathrm{mM}$ (both showed $80 \%$ inhibition at 1 $\mathrm{mM}$ ). Linoleic acid was found to be the most potent of the three fatty acids tested with an $\mathrm{IC}_{50}$ of 64 $\mu \mathrm{M}$. The reference compound dexamethasone had an $\mathrm{IC}_{50}$ of $5 \mathrm{nM}$.

\section{Experimental}

\subsection{General experimental procedures.}

All solvents used were Omnisolv HPLC grade and $\mathrm{H}_{2} \mathrm{O}$ used was Millipore Milli-Q PF filtered. Optical rotations were measured on a JASCO P-1020 polarimeter $(10 \mathrm{~cm}$ cell). UV spectra were recorded on a 
CAMSPEC M501 UV/vis spectrophotometer and IR spectra were recorded on a Bruker Tensor 27 spectrometer. NMR spectra were recorded at $30^{\circ} \mathrm{C}$ on Varian Inova $600 \mathrm{MHz}$ NMR spectrometer. Samples were dissolved in $\mathrm{CDCl}_{3}$ and chemical shifts were calculated relative to the proto-deutero solvent peak at $\delta_{\mathrm{H}} 7.26$ and $\delta_{\mathrm{C}}$ 77.0. $2 \mathrm{D}$ NMR spectra were recorded at $30^{\circ} \mathrm{C}$ using standard Varian pulse sequences for gCOSY, gHMQC, gHMBC and NOESY. LRESIMS were recorded on a Fisons VG Platform II mass spectrometer. HRESIFTMS were recorded on a Bruker Daltonics APEX III 4.7e FT mass spectrometer equipped with an Apollo API source. Alltech Davisil 30-40 $\mu \mathrm{m} 60 \AA \mathrm{A}_{18}$ Silica gel were used for flash chromatography separations. HPLC separations were achieved using a Rainin Microsorb $\mathrm{C}_{18}$ semipreparative column $(3 \mu \mathrm{m}, 10 \mathrm{~mm} \times 50 \mathrm{~mm})$.

\subsection{Plant material.}

The seeds of $C$. subspicata were collected by Paul Grimshaw on the $20^{\text {th }}$ of April 1994 from Gus Beutels Lookout, Ravensbourne National Park, in South East Queensland. A voucher specimen, AQ600876, is deposited at the Queensland Herbarium.

\subsection{Extraction and isolation.}

The ground seeds of $C$. subspicata. $(5 \mathrm{~g})$ were extracted with $\mathrm{CH}_{2} \mathrm{Cl}_{2}(200 \mathrm{ml})$ yielding a brown gum $(1.29 \mathrm{~g})$

The $\mathrm{CH}_{2} \mathrm{Cl}_{2}$ extract was partitioned between $90 \%$ aq $\mathrm{MeOH}(50 \mathrm{ml})$ and hexane $(3 \times 50 \mathrm{ml})$. The hexane fraction (1140 mg) was analyzed by (-) ESIMS and ions at $m / z$ 255, 281 and 279 were observed. The ${ }^{1} \mathrm{H}$ NMR of this fraction was characterized by signals that were indicative of both saturated and unsaturated fatty acids. The aq. $\mathrm{MeOH}$ soluble material $(150 \mathrm{mg})$ was fractionated on a $\mathrm{C}_{18}$ flash column using a $5 \%$ stepwise gradient from $50 \% \mathrm{MeOH} / 50 \% \mathrm{H}_{2} \mathrm{O}$ to $\mathrm{MeOH}$. The $25 \% \mathrm{H}_{2} \mathrm{O} / 75 \% \mathrm{MeOH}$ fraction was further fractionated by $\mathrm{C}_{18} \mathrm{HPLC}$ with a linear gradient from $\mathrm{H}_{2} \mathrm{O} / \mathrm{MeOH}(1: 1)$ to $70 \%$ 
$\mathrm{MeOH} / 30 \% \mathrm{H}_{2} \mathrm{O}$ to yield compound 1 (9.3 mg, $0.19 \%$ dry weight). The $15 \% \mathrm{H}_{2} \mathrm{O} / 85 \% \mathrm{MeOH}$ fraction was purified by $\mathrm{C}_{18} \mathrm{HPLC}$ with a linear gradient from $40 \% \mathrm{H}_{2} \mathrm{O} / 60 \% \mathrm{MeOH}$ to $30 \% \mathrm{H}_{2} \mathrm{O}$ / $70 \% \mathrm{MeOH}$ to yield compound 2 (6.5 mg, $0.13 \%$ dry weight).

\subsection{1. $1 \alpha$-acetoxy-4 $\beta, 8 \alpha$-dihydroxy-6 $\beta, 9 \alpha$-dibenzoyl- $\beta$-agarofuran (1)}

Colourless gum; $[\alpha]-27.5^{\circ}\left(c 0.14, \mathrm{CHCl}_{3}\right) .19 \mathrm{D} ; \mathrm{UV} \lambda_{\max }^{\mathrm{MeOH}} \mathrm{nm}(\log \varepsilon): 234$ (4.41), 272 (3.55); IR $v_{\text {max }}^{\mathrm{KBr}} \mathrm{cm}^{-1}: 3468 \mathrm{br}, 2934,1730,1719,1601,1584,1236,1176,1070 ;{ }^{1} \mathrm{H}\left(\mathrm{CDCl}_{3}, 600 \mathrm{MHz}, \delta\right): 8.21$ $\left(1 \mathrm{H}, \mathrm{dd}, 7.8,2.2 \mathrm{~Hz}, 1 \mathrm{H}-3^{\prime}\right.$ and 1H-7'), $8.11\left(2 \mathrm{H}, \mathrm{dd}, 7.8,2.2 \mathrm{~Hz}, 1 \mathrm{H}-3^{\prime \prime}\right.$ and 1H-7"), 7.61 (2H, td, 7.8, $\left.2.2 \mathrm{~Hz}, 1 \mathrm{H}-5^{\prime \prime}\right), 7.58$ (1H, t, $\left.7.8 \mathrm{~Hz}, 1 \mathrm{H}-5^{\prime}\right), 7.49$ (2H, dd, 7.8, $7.8 \mathrm{~Hz}, 1 \mathrm{H}-4 "$ and 1H-6"), 7.47 (2H, dd, 7.8, 7.8, Hz, 1H-4' and 1H-6'), $6.46(1 \mathrm{H}, \mathrm{s}, 1 \mathrm{H}-6), 5.54(1 \mathrm{H}, \mathrm{d}, 4.8 \mathrm{~Hz}, 1 \mathrm{H}-9), 5.15$ (1H, dd, 3.6, 12.9, Hz, 1H-1), 4.47 (1H, dd, 4.2, 4.8 Hz, 1H-8), 2.63 1H, (d, $4.2 \mathrm{~Hz}, 1 \mathrm{H}-7), 1.89$ (1H, ddd, 14.4, 13.2, 2.4

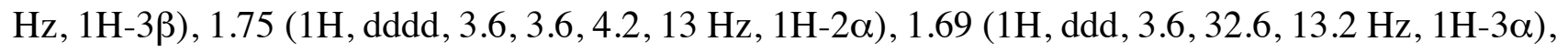
1.63 (3H, s, 3H-15), 1.57 (3H, s, 3H-14), 1.58 (3H, s, 3H-13), 1.52 (1H, dddd, 12, 13, 14.4, $3.6 \mathrm{~Hz}, 1 \mathrm{H}-$ 2ß), 1.43 (3H, s, 3H-1Ac), 1.39 (3H, s, 3H-11); $\left.{ }^{13} \mathrm{C} \mathrm{NMR} \mathrm{(} \mathrm{CDCl}_{3}, 150 \mathrm{MHz}, \delta\right): 170.2$ (1-OCOCH3), 166.0 (C-1'), 165.1 (C-1"), 133.5 (C-5"), 133.2 (C-5'), 130.2 (C-3' and C-7'), 130.0 (C-2' and C-2"), 129.7 (C-3" and C-7"), 128.7 (C-4" and C-6"), 128.6 (C-4' and C-6'), 92.7 (C-5), 83.0 (C-12), 78.2 (C-1), 76.5 (C-9), 75.7 (C-6), 70.5 (C-4), 70.0 (C-8), 54.4 (C-7), 49.8 (C-10), 38.7 (C-3), 29.7 (C-14), 24.1 (C2), 23.8 (C-13), 23.5 (C-11), 20.8 (1-OCOCH $), 13.2$ (C-15); (+)-HRESIFTMS m/z 575.2268 [M + $\left.\mathrm{Na}^{+}\right]^{+}$(calcd for $\mathrm{C}_{31} \mathrm{H}_{36} \mathrm{O} 9 \mathrm{Na}, 575.2252$ )

\subsection{2. $1 \alpha, 8 \alpha$-diacetyl-4 $\beta$-hydroxy-6 $\beta, 9 \alpha$-dibenzoyl- $\beta$-agarofuran (2)}

Colourless gum; $[\alpha]-24.7^{\circ}\left(c 0.14, \mathrm{CHCl}_{3}\right) .19 \mathrm{D} ; \mathrm{UV} \lambda_{\max }^{\mathrm{MeOH}} \mathrm{nm}(\log \varepsilon): 233$ (4.44), 273 (3.70); IR $v_{\max }^{\mathrm{KBr}} \mathrm{cm}^{-1}: 3544 \mathrm{br}, 2946,1745,1721,1452,1368,1274,1232,1110,713 ;{ }^{1} \mathrm{H}\left(\mathrm{CDCl}_{3}, 600 \mathrm{MHz}, \delta\right):$ $8.21\left(1 \mathrm{H}, \mathrm{dd}, 7.8,2.2 \mathrm{~Hz}, 1 \mathrm{H}-3^{\prime}\right.$ and $\left.1 \mathrm{H}^{-} 7^{\prime}\right), 8.11\left(2 \mathrm{H}, \mathrm{dd}, 7.8,2.2 \mathrm{~Hz}, 1 \mathrm{H}-3^{\prime \prime}\right.$ and $\left.1 \mathrm{H}-7^{\prime \prime}\right), 7.61(2 \mathrm{H}, \mathrm{td}$, 7.8, $\left.2.2 \mathrm{~Hz}, 1 \mathrm{H}-5^{\prime \prime}\right), 7.58$ (1H, t, $\left.7.8 \mathrm{~Hz}, 1 \mathrm{H}-5^{\prime}\right), 7.49$ (2H, dd, 7.8, $7.8 \mathrm{~Hz}, 1 \mathrm{H}-4 "$ and 1H-6"), 7.47 (2H, dd, 7.8, 7.8, Hz, 1H-4' and 1H-6'), $6.26(1 \mathrm{H}, \mathrm{s}, 1 \mathrm{H}-6), 5.64(1 \mathrm{H}, \mathrm{d}, 4.8 \mathrm{~Hz}, 1 \mathrm{H}-9), 5.59$ (1H, dd, $4.2,4.8$ Hz, 1H-8), 5.18 (1H, dd, 3.6, 11.4 Hz, 1H-1), 2.63 (1H, d, 4.2 Hz, 1H-7), 2.18 (3H, s, 8-OAc), 1.90 (1H, ddd, 13.2, 13.2, 4.8 Hz, 1H-3ß), $1.76(1 \mathrm{H}$, dddd, 3.6, 3.6, 4.8, $13.2 \mathrm{~Hz}, 1 \mathrm{H}-2 \alpha), 1.72(1 \mathrm{H}, \mathrm{ddd}, 3.6$, 
3.6, $13.2 \mathrm{~Hz}, 1 \mathrm{H}-3 \alpha), 1.67$ (3H, s, 3H-13), 1.61 (3H, s, 3H-15), 1.56 (1H, dddd, 11.4, 13.2, 13.2, 3.6 Hz,

$1 \mathrm{H}-2 \beta), 1.55$ (3H, s, 3H-14), $1.42(3 \mathrm{H}, \mathrm{s}, 3 \mathrm{H}-1 \mathrm{Ac}), 1.40(3 \mathrm{H}, \mathrm{s}, 3 \mathrm{H}-11) ;{ }^{13} \mathrm{C} \mathrm{NMR}\left(\mathrm{CDCl}_{3}, 150 \mathrm{MHz}\right.$,

ঠ): $170.1\left(1-\mathrm{OCOCH}_{3}\right), 169.9\left(8-\mathrm{OCOCH}_{3}\right), 165.9\left(\mathrm{C}-1^{\prime}\right), 165.1\left(\mathrm{C}-1^{\prime \prime}\right), 133.5\left(\mathrm{C}-5^{\prime \prime}\right), 133.2\left(\mathrm{C}-5^{\prime}\right), 130.2$

(C-3' and C-7'), 130.0 (C-2' and C-2"), 129.7 (C-3" and C-7"), 128.7 (C-4" and C-6"), $128.6(\mathrm{C}-4$ ' and C-

6'), 92.5 (C-5), 83.3 (C-12), 77.8 (C-1), 74.2 (C-9), 76.1 (C-6), 71.2 (C-8), 70.7 (C-4), 52.5 (C-7), 49.8

(C-10), 38.7 (C-3), 29.5 (C-14), 24.3 (C-2), 23.9 (C-13), 23.4 (C-11), 20.8 (1-OCOCH $), 20.7$ (8-

$\left.\mathrm{OCOCH}_{3}\right), 12.8(\mathrm{C}-15)$; (+)-HRESIFTMS $m / z 617.2348\left[\mathrm{M}+\mathrm{Na}^{+}\right]^{+}$(calcd for $\mathrm{C}_{33} \mathrm{H}_{38} \mathrm{O}_{10} \mathrm{Na}$,

617.2357)

\subsection{Assay procedure}

\subsubsection{Glucocorticoid Gene Down Regulation Assay and $\beta$-Galactosidase Assay}

The experimental details for the Glucocorticoid Gene Down Regulation Assay and $\beta$-Galactosidase assays have been described previously (Carroll et al., 2008).

\subsubsection{Cytotoxicity Assay.}

HeLa cells were plated at $1 \times 10^{4}$ cells/ml into a flat-bottom, 96-well microtitre plate containing either compound 1 or $\mathbf{2}$. The cells were then continuously exposed to the compounds for 5 days. After 5 days the media was removed and replaced with $200 \mu 1$ of media containing Neutral Red $(50 \mu \mathrm{g} / \mathrm{ml})$. Cells were then incubated for $3 \mathrm{~h}$ at $37^{\circ} \mathrm{C}$ in a $5 \% \mathrm{CO}_{2}$ atmosphere. The cells were then washed twice with PBS and destained with $200 \mu 1$ of destaining solution (1\% glacial acetic acid and $50 \%$ ethanol) by shaking on a Bioline Orbital Shaker (Quantum Scientific Pty Ltd, Australia) for 10 min. The

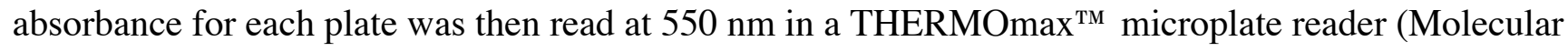


Devices, CA, USA). $\mathrm{IC}_{50}$ values for the isolated compounds were obtained by testing three wells per concentration.

\section{Acknowledgments}

We thank AstraZeneca for financial support. We thank Mr H. T. Vu (Griffith University) for obtaining accurate mass measurements.

\section{References}

Bamberger, C. M.; Schulte, H. M.; Chrousos, G. P. 1996. Molecular determinants of glucocorticoid receptor function and tissue sensitivity to glucocorticoids. Endocr. Rev. 17, 245-261.

Brüning, R., Wagner, H., 1978. Übersicht über die celastraceen-inhaltsstoffe: Chemie, Chemotaxonomie, biosynthese, pharmakologie. Phytochemistry 17, 1821-1858.

Carroll, A. R., Addepalli, R., Fechner, G., Smith, J., Guymer, G. P., Forster, P. I., Quinn, R. J. 2008. Alkaloids from the Australian Rainforest Tree Ochrosia moorei. J. Nat. Prod. 71, 1063-1065.

Chang, F. -R., Hayashi, K., Chen, I. -H., Liaw, C. -C., Bastow, K. F., Nakanishi, Y., Nozaki, H., Cragg, G. M., Wu, Y. -C., Lee, K. -H. 2003. Antitumor Agents. 228. Five New Agarofurans, Reissantins A-E, and Cytotoxic Principles from Reissantia buchananii. J. Nat. Prod. 66, 1416-1420.

Duan, H., Takaishi, Y., Bando, M., Kido, M., Imakura, Y., Lee, K. -H., 1999. Novel sesquiterpene esters with alkaloid and monoterpene and related compounds from Tripterygium hypoglaucum. A new class of potent anti-HIV agents. Tetrahedron Lett. 40, 2969-2972.

Hayashi, R., Wada, H., Ito, K., Adcock, I. M., 2004. Effects of glucocorticoids on gene transcription. Eur. J. Pharmacol. 500, 51-62. 
Kumar, R., Thompson, E. B., 2005. Gene regulation by the glucocorticoid receptor: structure: function relationship. J. Steroid Biochem. Mol. Biol. 94, 383-394.

Kuo, Y. -H., King, M. -L., Chen, G. -F., Chen, H -Y., Chen, C. -H., Chen, K., Lee, K. -H., 1994. Two new macrolide sesquiterpene pyridine alkaloids from Maytenus emarginata: Emarginatine $\mathrm{G}$ and the cytotoxic Emarginatine F. J. Nat. Prod. 57, 263-269.

Nicolaou, K. C., Pfefferkorn, J. A., Roecker, A. J., 2000. Natural product-like combinatorial libraries based on privileged structures. 1. General principles and solid phase synthesis of benzopyrans. J. Am. Chem. Soc. 122, 9939-995.

Pujols, L., Mullol, J., Torrego, A., Picado, C., 2004. Glucocorticoid receptors in human airways. Allergy $59,1042-1052$.

Tu, Y. Q., Chen, Y. Z., Wu, D. G., Zhang, X. M., Hao, X. J., 1993. Sesquiterpenoids from Celastrus paniculatus. J. Nat. Prod. 56, 122-125.

Wu, W., Wang, M., Zhu, J., Zhou, W., Hu, Z., Ji, Z., 2001. Five new insecticidal sesquiterpenoids from Celastrus angulatus. J. Nat. Prod. 64, 364-367.

Zheng, Y. L., Xu, Y., Lin, J. F., 1989. Immunosuppressive effects of wilfortrine and enonine. Yaoxua Xuebao 24, 568-572. 


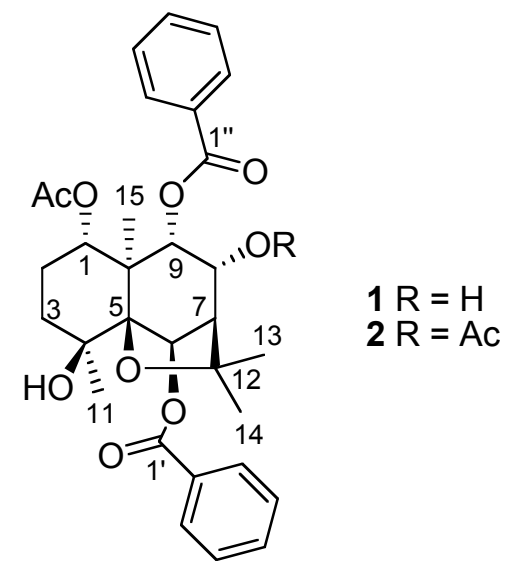

Fig. 1. Agarafurans (1 and 2) isolated from Celastrus subspicata 